\title{
Communication patterns cares for children and Deli river in building the moral of children in the River
}

\author{
Sima Insani ${ }^{\mathrm{a}, 1, *}$, Abrar Adhani ${ }^{\mathrm{b}, 2}$ \\ ${ }^{a}$ University of Muhammadiyah Sumatera Utara, Jl. Kapten Muchtar Basri No.3, Glugur Darat II, Kec. Medan Tim., Kota Medan, Sumatera Utara 20238 \\ 1 shimainsany1806@gmail.com*; ${ }^{2}$ abraradhani@umsu.ac.id \\ * corresponding author
}

\begin{abstract}
Article history

Received 09-11-2021

Revised 10-11-2021

Accepted 11-11-2021

A group of people who have the same goals and vision will form a group. A group can be used as a forum to communicate and exchange ideas and information. In exchanging information, ideas, and ideas some patterns have been agreed upon by the group. This study aims to determine the communication patterns formed by the Child Care Community and the Deli River in building children's morale on the riverside. This research uses a descriptive qualitative approach by

Keywords collecting data through observation, in-depth interviews, and literature

Communication Patterns study. The results showed that there were forms of communication patterns from the child care community and the Deli River in building

Morals

Children the morale of the children on the riverbank, with various patterns of one-way communication, two-way communication.
\end{abstract}

This is an open access article under the CC-BY-SA license.

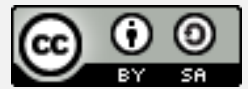

\section{Introduction}

As time goes by, social problems are also getting more complex. These complex social problems occur because the values and norms that have been agreed upon and held by the community conflict with unexpected social conditions. The unmet needs of life are one of the causes of this social problem to arise. As a result of the unfulfilled necessities of life, it will cause a deviation of values in society. These social problems can be overcome by conducting empowerment and communication that is simple and easy to understand to the parties involved in the empowerment process so that the purpose of this empowerment can be achieved (Brenner \& Igamberdiev, 2021).

Community groups who have more knowledge or are more empowered can carry out the empowerment process for people who do not understand an object's empowerment. The implementation of empowerment can be carried out by people who have the ability and understanding of the problems faced, whether it is carried out by the official government, private, non-governmental organizations, community organizations, or communities that are deliberately formed for these empowerment activities (Palla, Barabási, \& Vicsek, 2007).

A community is a group consisting of people who care about one another, and these people have personal relationships that are so close to the members of their community that they can share common values. People who are in communication are expected to be committed to conveying their vision and mission to society so that the common good can be realized.

Various communities have emerged recently due to the many social problems that occur in the community, such as acts of violence, sexual harassment, various legal irregularities involving children as perpetrators and victims. One of the communities that have emerged highlighting these cases is the community that cares for child development and education. This community has emerged and formed in various regions of Indonesia, especially the city of Medan. In Medan, this community is called KOPASUDE or the Child Care Community and the Deli River. Kopasude has 
only been present since 2014 in Badur Village. A densely populated settlement formed right on Jalan Badur next to the PTPN IV office (Jandevi, 2019).

Activities and programs from KOPASUDE are directed at children so that they can contribute to their environment, therefore, parties such as the surrounding environment and parents must also play a role in the internal interactions of the community. KOPASUDE programs will be easier to implement if supported and given supervision from various parties, especially parents. KOPASUDE community members must have the right communication pattern as a form of empowerment process for children. KOPASUDE can create appropriate and comfortable learning patterns for children because this will make them happy, comfortable, feel valued, and loved and can be a place to develop themselves.

\section{Theorotocal Framework}

\section{a) Communication Patterns}

The communication pattern is a system that is interconnected with one another which consists of several components to realize education during society. Patterns are also referred to as shapes or models that are always used to make or produce parts of something, especially if the resulting pattern has a visible or demonstrated basic pattern (Kartika Ekasari et al., 2013).

The idea is the initial concept of communication. The idea is transformed and processed into a message and sent using the media to the recipient of the message, after which it is processed to be understood and conveyed again the meaning of the message to the message giver. The response given by the recipient will be a measure in seeing the extent to which the message is known and understood by the person receiving the message.

According to Effendy (2009), there are three kinds of patterns in communication, namely: (1) One-way communication pattern, which is a process in delivering messages from a communicator to communication using or without using media, and has no feedback because communication is only as a listener, (2) Two-way or reciprocal communication patterns are communication that occurs between the communicator and the communicant in which they exchange information and carry out their respective functions, and feedback occurs continuously, (3) Multi-way Communication Pattern, namely communication that occurs in a group where the communication process that occurs between the communicator and the communicant will exchange ideas in a dialogical manner.

\section{b) Interpersonal Communication}

Interpersonal or interpersonal communication is communication that is done face to face (face to face) where the communicator and the communicant can see the response directly, both verbally and nonverbally (Berger \& Roloff, 2019).

Interpersonal communication that occurs between two people is a psychological process that places an understanding of communication and interpersonal relationships. The individuals involved in the communication have their understanding and meaning for them. From the psychological aspect, the most important thing in communication about personal self will not be directly observed by other individuals. Thus, the observations that occur in interpersonal communication are made through the behavior and perceptions of the observer.

\section{c) Moral}

The actions of a person as a way of judging one's life properly concerning what is good and bad are called morals. Moral also means insight and knowledge regarding civilized human behavior. Humans who have positive values are called moral while humans who have negative values are called immoral (amoral). Therefore, everyone needs to have morals (Horn \& Schönecker, 2008).

Understanding of morals has six stages in it, namely: (a) The Morality of Obedience. In the first stage of moral understanding, a human being is influenced by the strength of others. Someone understands that the way of life between one another is to obey or do the words of others, for those who do not obey will get punishment. Thus, at this stage, what is considered good and right moral is to obey and do the words of those who are more powerful, (b) The Morality of Egoism and simple 
exchange. In this second stage of moral understanding, each individual has an awareness of the interests and desires he wants. It is considered good morals to do something self-fulfilling, and there is no need to do what other people ask. Even though this stage is self-centered, there is a concept of how individuals work together, make short-term agreements, and exchange benefits. Cooperation becomes a platform for the simplest exchange of kindness.

The Morality of Interpersonal concordance. The third stage of this moral understanding concerns individuals who are aware of other individual relationships not only in short-term agreements, but also in long-term relationships, such as loyalty, words and gratitude, and a sense of concern. At this stage, the relationship built by the individual does not need to be concerned with reciprocation. This stage emphasizes commitment and loyalty. Maintaining relationships with other people is at the core of the concept of cooperation at this stage. Also, the moral in this third stage includes reciprocal role-taking, where individuals try to take the point of view and roles of other individuals, and other individuals also do the same. Therefore, this stage makes individuals try to build and maintain relationships by paying attention, showing loyalty, and being kind (Bentham, 2020).

The Morality of Low and Duty To Social Order. By looking at the shortcomings that exist in the third stage, this fourth stage provides a basis for society in general for cooperation, not only with friends but also with strangers and enemies. This can be done with legal assistance (law). Thus society can be governed by laws and regulations with the hope that everyone will have behavior by the law.

The Morality of consensus-building procedure. Hold this fifth, interpreting morality through a political approach. Political mechanisms ranging from elections, polling, voting in making decisions are a sign of reaching group agreement. To decide what is right, it will be decided together.The Morality of Non-Arbitrary Social Cooperation. This last stage has the perception of a society that can ideally balance the benefits and burdens in life, and seek more for the welfare of everyone (Pribadi \& Nasution, 2021).

\section{Method}

This research uses qualitative research. According to Moleong (2018), qualitative research is research that aims to understand the phenomena experienced by research subjects. The phenomena experienced can be seen from behavior, actions, opinions, motivations, and so on. Furthermore, qualitative research will describe this phenomenon into natural language and words and utilize various natural methods. Qualitative research has three models in research design, namely descriptive, verification, and grounded research.

\section{Results and Discussion}

\section{1) Linear or one-way communication}

When someone gives a message to another, but the message is not responded to by the recipient, what happens is one-way communication. Communication that takes place from one party only, in other words, the sender of the message does not allow the recipient to respond or respond to the message. In terms of the moral formation of children on the riverbank.

One-way communication is considered less effective because this communication results in younger students becoming unaccustomed to expressing their opinions and thoughts well, being inactive, and unable to be creative. Supposedly in this super-fast era, the younger generation needs intelligence and creativity to meet the demands of the times. Moreover, this one-way communication model is a form of authoritarian communication, communicants may feel depressed and undergo orders unhappily. But on the other hand, one-way communication is very appropriate to make children more disciplined in their daily activities, as well as forming their independence so that they obey parental orders, to volunteer siblings, politeness with elders (Shannon, 1997). 


\section{2) Interaction or Two-Way Communication}

When there is communication with someone by sending messages, ideas, or ideas and the message gets a response or responses from the recipient of the message, it is called two-way communication. Two-way communication between the sender and recipient of the message has feedback from each other. This is like having a vent session or telling everything that is being experienced or felt by the communicator and the communicant giving a response or responding to what the communicator said (Brenner \& Igamberdiev, 2021).

When dealing with children who cannot obey, have problems with friends, and learning achievement levels decline, two-way communication patterns are used. Dialogue or two-way communication can be the right solution in this situation because, with two-way communication, volunteers can provide understanding and understanding of the child about the situation at hand. Even so, the use of two-way communication by volunteers varies according to the situation at hand and tends to dominate using two-way communication patterns.

\section{3) Multi-Directional Communication (Transaction)}

Communication can be a transaction that not only involves dynamic interaction between the sender and receiver of the message but also involves other elements. It can be called multi-way communication. Multi-directional communication aims to elicit responses from children when they listen to conversations from chaperones. Therefore, it can be said that at the same time this communication has many senders and recipients of messages. This method of learning with communication patterns has various ways, such as teaching independence and discipline, by giving examples through actions so that they can see and make it an experience to learn, discussing to foster critical attitudes, letting children determine their peers, and teaching children to love themselves. Some volunteers also often hold light discussions with their younger students when teaching, so that according to the students will be trained in critical thinking, students can learn more often, be active and can train cooperation with their friends, and a leadership spirit is formed from when they were small. Even though it looks simple and ordinary, if it is done regularly, the character of the students who are active, critical, and their leadership spirit can be formed easily (Williamson, 2019).

\section{4) Persuasive Communication}

A relationship with a child can be harmonious if someone has communicated and produced an emotional relationship. The more often someone communicates and is close to someone, the more psychologically a person will be related or connected. This condition will be very useful for each other's closeness to bring out feelings of a mutual need for one another. The informant explained that the volunteers tried to maintain communication with the students by not talking harshly with them. Based on the observations made, the children's verbal disrespect was influenced by the way their parents spoke, then then the friendship environment factor. Some parents, if angry, do not realize how to speak harshly to their children which the child should not hear, because children will imitate and will interpret the understanding of events that take place before their eyes, regardless of whether the incident is good or bad. Based on the results of the study, the researcher found that children's moral building can be used by making effective communication. Effective communication is persuasive communication. Persuasive communication is communication that is done to try to influence the mind, persuade so that it can change children's behavior so that they can have a better attitude than before. As a volunteer so that children can be influenced or interested, they are given good hopes and give promises with beneficial things so that the children accept to fulfill the volunteer invitation to change their behavior and follow what is ordered (Young, 2016).

Exemplary Method. The exemplary method is a coaching method that is carried out by providing good examples in every action or by speaking good words so that they are easily understood and imitated by children. Exemplary methods can be done by communicating verbally or non-verbally. The exemplary method can be applied by requiring persuasive communication (influencing) so that children can be affected emotionally.

Habitual Method. The habituation method becomes a method that can also make children kinder and more polite. Children will get used to doing something if they are accustomed to good habits 
first so they will do something without having to be ordered. Psychology and thoughts will be easily influenced by focusing on using persuasive communication to change the child's behavior.

\section{Conclusion}

In general, the use of two-way communication patterns is more dominant compared to the use of linear communication patterns and communication patterns transactions except in situations of regulating children's allowance and time utilization Children's leisure use of transaction communication patterns is more dominant. Meanwhile, interaction communication patterns are most widely used when dealing with children who are problems with friends, decreased learning achievement of children, and if a communicator cannot fulfill the child's request. This communication serves to provide understanding to children about the situation at hand. Transaction communication patterns rank second as the communication patterns used in this research. Children are allowed to participate in decisions something in a balanced portion while the communication pattern is one-way used in disciplining children in carrying out daily activities. Meanwhile, persuasive communication leads to the emotional aspect of how to persuade, influence the child's mind so that it can change behavior and can form a better attitude than before.

\section{Acknowledgment}

My gratitude goes to all those who have helped to complete this research. Thank you also to the Communication Science Study Program of the Muhammadiyah University of North Sumatra which has become a place to gain knowledge so that it remains superior, smart, and trusted.

\section{References}

Bentham, J. (2020). An Introduction to the Principles of Morals and Legislation. In Princeton Readings in Political Thought. https://doi.org/10.2307/j.ctv19fvzzk.34

Berger, C. R., \& Roloff, M. E. (2019). Interpersonal communication. In An Integrated Approach to Communication Theory and Research, Third Edition. https://doi.org/10.4324/9780203710753-24

Brenner, J. E., \& Igamberdiev, A. U. (2021). Communication. In Studies in Applied Philosophy, Epistemology and Rational Ethics. https://doi.org/10.1007/978-3-030-62757-7_12

Effendy, O. U. (2009). Ilmu Komunikasi, Teori dan Praktek. In Komunikasi dalam sebuah organisasi.

Horn, C., \& Schönecker, D. (2008). Groundwork for the metaphysics of morals. In Groundwork for the Metaphysics of Morals. https://doi.org/10.1017/cbo9780511809590.004

Jandevi, U. (2019). Communication strategy to improve women's political participation in Indonesia. International Journal of Communication and Society, 1(2), 68-81. https://doi.org/10.31763/ijcs.v1i2.46

Kartika Ekasari, Z., Saleh, S. A. M., Jusoff, K., Salman, D., Akhsan, Kasirang, A., ... Fudjaja, L. (2013). Communication pattern and conflict in agricultural extension. Asian Social Science. https://doi.org/10.5539/ass.v9n5p27

Moleong, L. J. (2018). Metodologi Penelitian Kualitatif, cet. In XI. Bandung: PT Remaja Rosdakarya.

Palla, G., Barabási, A. L., \& Vicsek, T. (2007). Quantifying social group evolution. Nature. https://doi.org/10.1038/nature05670

Pribadi, A., \& Nasution, N. (2021). Digital transformation to the sustainability of public relations profession in the era of disruption. Commicast, 2(1), 52. https://doi.org/10.12928/commicast.v2i1.3149

Shannon, C. E. (1997). The Mathematical Theory of Communication. M.D. Computing. https://doi.org/10.2307/410457

Williamson, O. E. (2019). Transaction-cost economics: The governance of contractual relations. In Corporate Governance: Values, Ethics and Leadership. https://doi.org/10.1086/466942

Young, R. (2016). Persuasive Communication. In Persuasive Communication. https://doi.org/10.4324/9781315687117 